\title{
IDENTIFICATION OF BACTERIAL AGENTS OF ENTERIC DISEASES BY MULTIPLEX PCR IN GROWING-FINISHING PIGS
}

\author{
Maria Regina Baccaro*; Andrea Micke Moreno; Luciane Tieko Shinya; Daniela Sabatini Dotto \\ Faculdade de Medicina Veterinária e Zootecnia, Universidade de São Paulo, São Paulo, SP, Brasil. \\ Submitted: May 03, 2002; Returned to Authors: December 17, 2002; Approved: September 30, 2003
}

\begin{abstract}
In Brazil, the most common bacterial enteric diseases affecting growing and finishing pigs are porcine proliferative enteritis, porcine intestinal spirochetosis, swine dysentery, and salmonellosis. The diagnosis of these diseases by routine culture techniques is expensive, difficult, time-consuming, and even impossible, in cases of porcine proliferative enteritis. The detection of pathogens by polymerase chain reaction is a highly sensitive and specific method that can be an useful tool in veterinary diagnosis. Two multiplex PCR (M-PCR) assays were tested for simultaneous detection and identification of bacterial agents associated with porcine proliferative enteritis, porcine intestinal spirochetosis, swine dysentery, and salmonellosis in diarrheic fecal samples. The DNA obtained from pure cultures of each bacterial agent or mixed in different combinations and concentrations was amplified by using Lawsonia intracellularis and Salmonella, or Brachyspira pilosicoli and Brachyspira hyodysenteriae specific M-PCR assays. After electrophoresis in agarose gel and staining, the amplification products indicated the presence of individual or simultaneous amplification of $L$. intracellularis and Salmonella or B. pilosicoli and B. hyodysenteriae specific DNA sequences. After standardization, the M-PCR tests were used to test 541 swine diarrheic fecal samples obtained from different regions in Brazil. The most frequently detected pathogen was Lawsonia intracellularis (13\%), followed by Salmonella (4.8\%), B. hyodysenteriae (1.4\%), B. pilosicoli (1\%) and their various associations. Results from this study suggest that the two M-PCR assays can be used for specific detection and identification of four important enteric bacterial pathogens alone or in combination.
\end{abstract}

Key words: enteritis, PCR, pig, bacteria, diagnosis.

\section{INTRODUCTION}

It is necessary to accurately detect and identify porcine pathogens (5) in order to devise proper treatment and prevention programs. Porcine proliferative enteritis (PPE) caused by Lawsonia intracellularis (16), porcine intestinal spirochetosis (PIS) caused by Brachyspira pilosicoli (24), swine dysentery (SD) caused by Brachyspira hyodysenteriae (11) and porcine salmonellosis (PS) caused by Salmonella (25) are the most common diarrhea-causing bacterial diseases affecting pigs during the growing finishing stages of production. The economic impact of these diseases on pig production results in mortality, growth rate losses and substantial antibiotic costs (16).
The diseases caused by L. intracellularis, B. pilosicoli, $B$. hyodysenteriae, and Salmonella affect a similar age groups during the production cycle. These agents are transmitted by the fecal-oral route and their isolation and identification can take-up to several days or weeks and the results are not always definitive $(8,9)$. Diagnosis of enteric diseases has been made on basis of clinical signs, isolation of this etiologic agents for PIS, SD and PS and detection of $L$. intracellularis by PCR for PPE $(12,25)$.

Amplification of pathogen-specific DNA sequences using PCR is considered to be the future in diagnostics, because it increases sensitivity, specificity, besides allowing for a faster diagnosis (5). It has been shown that the detection of $L$.

*Corresponding author. Mailing address: Faculdade de Medicina Veterinária e Zootecnia, Universidade de São Paulo. Av. Dr. Orlando Marques de Paiva, 87. 05508-000, São Paulo, SP, Brasil. Tel.: (+5511) 3818-7708. Fax: (+5511) 3818-7829. E-mail: baccaro@usp.br 
intracellularis, B. hyodysenteriae, B. pilosicoli and Salmonella using specific DNA sequences (primers) and PCR amplification is more sensitive and specific than standard culture techniques for diagnosis of SD, PIS and PS and histopathological analysis for PPE $(1,12,18,22)$.

Currently, the use of PCR in veterinary medicine is still limited to a small number of diagnostic laboratories, the introduction of M-PCR can change this picture, since it allows for reducing the costs and time spent in the diagnosing enteric diseases maintaining however, the sensitivity and specificity of the original tests.

In Brazil, the incidence of the above-mentioned enteric pathogens is poorly studied, although diarrhea is commonly seen during growing and finishing. Therefore, this study aimed at standardizing the M-PCR by using different PCR tests previously described for diagnosing PPE, PIS, SD and PS, and to apply the M-PCR in the differential diagnosis of enteritis in pigs coming from different regions in Brazil.

\section{MATERIALS AND METHODS}

\section{Bacterial strains and growth conditions}

Brachyspira hyodysenteriae strain ATCC 49527 and Brachyspira pilosicoli strain ATCC 51139 were grown up to the late exponential phase (approximately $10^{8}$ cells $\mathrm{mL}^{-1}$ ) in prereduced Trypticase soy broth (PRAS), anaerobically sterilized, as described previously $(15,19)$. Broth cultures were constantly stirred at $37^{\circ} \mathrm{C}$ in a $10 \%$ hydrogen, $10 \%$ carbon dioxide, and $80 \%$ nitrogen atmosphere.

Salmonella Typhimurium ATCC 6994 was grown aerobically in Luria-Bertani broth at $37^{\circ} \mathrm{C}$. Purified DNA from $L$. intracellularis was isolated from organisms grown in cell culture as described previously (12).

\section{Fecal samples}

Five hundred and forty one fecal samples were obtained from seventy swine herds from the main pig producing regions in Brazil, including the states of São Paulo, Santa Catarina, Paraná, Rio Grande do Sul, Minas Gerais, Mato Grosso do Sul, Goiás. The diarrheic animals sampled were between 60 and 140 days old (growing - finishing stages).

\section{DNA extraction}

The procedure based on the binding of DNA to silicates in the presence of high guanidine thiocyanate ( $\mathrm{GuSCN}$ ) concentrations of was modified and used to extract total DNA of bacterial strains and fecal samples (4).

A sample of $0.3 \mathrm{~g}$ of feces or $200 \mathrm{~mL}$ of bacterial culture was added to a microtube and with a lytic guanidine thiocyanate solution and a diatom suspension. Then the tube was vortexed for $30 \mathrm{~s}$ and centrifuged $(12,000 \mathrm{x} \mathrm{g})$ for $15 \mathrm{~s}$ and the supernatant discarded. The pellet was washed twice with another guanidine thiocyanate solution, and twice with ethanol $70 \%$. Finally the pellet was washed with acetone and dried. A elution buffer was added to the pellet and it was heated to $56^{\circ} \mathrm{C}$ for $10 \mathrm{~min}$. The tube was centrifuged $12,000 \mathrm{x} \mathrm{g}$ for $5 \mathrm{~min}$ and the supernatant containing the DNA was used to M-PCR

\section{Primers and M- PCR reactions}

Primers for specific amplification of $L$. intracellularis, $B$. pilosicoli, B. hyodysenteriae and Salmonella are described in Table 1 . The primers were commercially synthesized (Life Technologies- Grand Island, NY) and tested for multiplex PCR with DNA obtained from bacterial strains alone and in different combinations.

Under our conditions, the use of the M-PCR as described by Elder et al. (8) resulted in preferential amplification of Salmonella, in detriment of $B$. hyodysenteriae detection (data not shown). In our laboratory, we were not able to amplify the DNA of L. intracellularis using the program described by these authors, nor include the B. pilosicoli primers. Based on the obtained results, we decided try other combinations of $B$. hyodysenteriae and B. pilosicoli primers. The primers pairs showing higher sensitivity and considered to be compatible to be used in one test tube reactions were selected for detection of B. pilosicoli and B. hyodysenteriae by M-PCR.

Two PCR amplification mixtures $(50 \mathrm{ml})$ were used, M-PCR1 consisted of $1 X$ PCR buffer, $1.5 \mathrm{mM} \mathrm{MgCl}_{2}, 200 \mathrm{mM}$ each dATP, dCTP, dGTP, dTTP, 50 pmol of each primer $(12,22)$, and $1.0 \mathrm{U}$ of Taq DNA polymerase (Life Technologies-Grand Island, NY), autoclaved, ultrapure water and $10 \mu \mathrm{L}$ of DNA template. MPCR 2 consisted of $1 X$ PCR bufer, $3 \mathrm{mM} \mathrm{MgCl}_{2}, 200 \mathrm{mM}$ each dATP, dCTP, dGTP, dTTP, 20 pmol of each primer $(1,13)$, and 1.0 U of Taq DNA polymerase (Life Technologies- Grand Island, NY), autoclaved, ultrapure water and $10 \mu \mathrm{L}$ of DNA template. Amplification was carried out in a DNA thermocycler (Model MJ Research 200). Different annealing temperatures were tested and two programs were selected for use in the M-PCR assays (Table 2). The amplified products were separated by electrophoresis in $2.0 \%$ agarose gel and stained with ethidium bromide. The 100 bp DNA ladder (Life Technologies- Grand Island, NY) was used as a molecular size marker.

In order to evaluate the effect of the number of bacterial cells on the sensitivity and specificity of the M-PCR assay, purified DNA from L. intracellularis, B. pilosicoli, B. hyodysenteriae and Salmonella were tested combined and alone in various dilutions to simulate concentrations among 1 to $10^{9}$ bacterial cells.

\section{RESULTS}

\section{M-PCR assays}

Different primers described for B. pilosicoli and $B$. hyodysenteriae detection were tested with various DNA concentrations and the pairs showing higher sensitivity were 
Table 1. Primers tested for multiplex PCR amplification of specific DNA sequences of L. intracellularis, B. pilosicoli, $B$. hyodysenteriae, Salmonella.

\begin{tabular}{l|l|c|c}
\hline \multicolumn{1}{c|}{ Agent } & \multicolumn{1}{|c|}{$\begin{array}{c}\text { Primers 5 -3 } \\
\text { (sense e antisense) }\end{array}$} & $\begin{array}{c}\text { Expected } \\
\text { Product }\end{array}$ & Reference \\
\hline L. $_{\text {intracellularis }}{ }^{a}$ & TATGGCTGTCAAACACTCCG TGAAGGTATTGGTATTCTCC & $319 \mathrm{pb}$ & 12 \\
Salmonella $^{a}$ & TGCCTACAAGCATGAAATGG AAACTGGACCACGGTGACAA & $457 \mathrm{pb}$ & 22 \\
B. hyodysenteriae $^{b}$ & GGTACAGGCGGAAACAGACTCCTAT TCTCTGACCTACTG & $1550 \mathrm{pb}$ & 7 \\
B. hyodysenteriae $^{b}$ & TTA AAA CAA GAA GGA ACT CTA ATA AAC GTC TGC TGC & $821 \mathrm{pb}$ & 1 \\
B. hyodysenteriae & ACC TAT TAT TTA ATT AAA CTT ATC GAA AAT ACT AAT AAA AGA CGG & $561 \mathrm{pb}$ & 10 \\
B. pilosicoli & TACGGCTACCTTGTACGACTT AGAGGAAAGTTTTTCGCTTC & $1300 \mathrm{pb}$ & 20 \\
B. pilosicoli $^{b}$ & TCCGCCTACTCACCCTTTAC AGAGGAAAGTTTTTCGCTTC & $361 \mathrm{pb}$ & 18 \\
\hline
\end{tabular}

${ }^{a}$ selected primers for utilization in M-PCR1 assay;

${ }^{\mathrm{b}}$ selected primers for utilization in M-PCR2 assay.

Table 2. Programs used for M-PCR DNA amplifications.

\begin{tabular}{crr|rrr}
\hline \multicolumn{3}{c|}{ Program 1 } & \multicolumn{3}{|c}{ Program 2 } \\
Temperature & Steps & Temperature & Steps \\
\hline $95^{\circ} \mathrm{C}$ & $5 \mathrm{~min}$ & 1 cycle & $96^{\circ} \mathrm{C}$ & $3 \mathrm{~min}$ & 1 cycle \\
$95^{\circ} \mathrm{C}$ & $1 \mathrm{~min}$ & $96^{\circ} \mathrm{C}$ & 1 min & \\
$55^{\circ} \mathrm{C}$ & 1 min & 38 cycles & $60^{\circ} \mathrm{C}$ & 1 min & 38 cycle \\
$72^{\circ} \mathrm{C}$ & 1,5 min & $72^{\circ} \mathrm{C}$ & 1,5 min & \\
$72^{\circ} \mathrm{C}$ & 5 min & 1 cycle & $72^{\circ} \mathrm{C}$ & 3 min & 1 cycle \\
\hline
\end{tabular}

selected for M-PCR assay (data not shown). M-PCR amplification of purified DNA from L. intracellularis, $B$. pilosicoli, B. hyodysenteriae and Salmonella in combination has not yielded the expected results. The expected products were obtained when L. intracellularis (319 bp) and Salmonella (457 bp) were amplified alone or in combination starting from various concentrations of DNA using the program 1 (annealing temperature of $\left.55^{\circ} \mathrm{C}\right)$. Amplification of L. intracellularis DNA was not possible with annealing temperature of $60^{\circ} \mathrm{C}$.

Amplification of B. pilosicoli (361bp) and B. hyodysenteriae (821bp) DNA products was obtained alone or in combination from different concentrations of DNA using program 2 (annealing temperature of $60^{\circ} \mathrm{C}$ ). Amplification of B. pilosicoli with annealing temperatures of $55^{\circ} \mathrm{C}$ produced nonspecific bands in fecal samples. When DNA of Salmonella were submitted to M-PCR with DNA of Brachyspira, a preferential amplification of DNA of Salmonella was observed.

The optimal $\mathrm{MgCl}_{2}$ concentration for reactions with $L$. intracellularis and Salmonella was $1.5 \mathrm{mM}$, while the optimal $\mathrm{MgCl}_{2}$ concentration for reaction of Brachyspira with selected primers was $3.0 \mathrm{mM}$. The use of $3.0 \mathrm{mM} \mathrm{MgCl}{ }_{2}$ concentration in L. intracellularis and Salmonella resulted in nonspecific bands. Lowered concentration of this salt in reactions with Brachyspira gave poor results. Based on these observations, two programs (Table 2) and two different reactions M-PCR1 ( $L$. intracellularis and Salmonella) and M-PCR2 (B. pilosicoli or $B$. hyodysenteriae) were used as described. These reactions yielded the expected results in detecting bacterial strains in different concentrations, with a sensitivity similar to previously described $(1,12,18,22)$. The sensibility values of PCR and MPCR for L. intracellularis, B. pilosicoli, B. hyodysenteriae and Salmonella were $10^{3}, 10^{3}, 10^{2}$, and $10^{2}$ bacterial cells respectively.

\section{Analysis of fecal samples}

The five hundred and forty one fecal samples tested resulted in $13 \%(70 / 541)$ samples positives for $L$. intracellularis, $4.8 \%$ (26/541) positives for Salmonella, $1 \%(5 / 541)$ positive for $B$. pilosicoli and $1.4 \%$ (8/541) positives for B. hyodysenteriae. The infections occurred either alone singly or in a variety of combinations, as shown in Table 3.

Table 3. Results obtained from detection of $L$. intracellularis, $B$. pilosicoli, B. hyodysenteriae and Salmonella in 541 fecal samples.

\begin{tabular}{lrc}
\hline \multicolumn{1}{c}{ Agent } & N & $\%$ \\
\hline L. intracellularis & 70 & 13 \\
B. pilosicoli & 5 & 1,0 \\
B. hyodysenteriae & 8 & 1,4 \\
Salmonella & 26 & 4,8 \\
L. intracellularis and B. Pilosicoli & 16 & 3,0 \\
L. intracellularis and Salmonella & 4 & 1,0 \\
B. hyodysenteriae and Salmonella & 2 & 0,4 \\
L. Intracellularis, B. pilosicoli and Salmonella & 2 & 0,4 \\
Negatives & 408 & 75 \\
Total & 541 & 100 \\
\hline
\end{tabular}

\section{DISCUSSION}

The amplification of purified DNA obtained from four different pathogens, in different dilutions, using two M-PCR assays, confirmed previous reports with individual PCR assay $(1,12,18,22)$. Amplification of specific 319-bp and 457-bp products were observed with M-PCR1 assays for L. intracellularis and 
Salmonella respectively. In addition, amplification of specific 361-bp and 821-bp products were obtained with M-PCR2 assay for B. pilosicoli and B. hyodysenteriae respectively. Under the described conditions, nonspecific amplification products were not detected in the M-PCR1 and M-PCR2 tests with purified bacterial DNA or with fecal samples.

The importance of $L$. intracellularis in Brazilian herds was previously described by Moreno et al. (17), reporting $15 \%$ of positive fecal samples (146/971). Similar results were obtained by Takahashi et al. (23), in Japan (14.9\% - 33/221). Chang et al. (6) in Taiwan (5.5\% - 31/560), Jordan et al., (13) in United States (5,6\% - 35/621) and Kim et al. (14) in Korea (3,3\% - 16/490) reported lower incidences than those observed in Brazil. Occurrence of healthy pigs carrying $L$. intracellularis and eliminating the agent intermittently in feces has been reported (16).

Though the fact that $6.6 \%$ of the pigs were shedding Salmonella, this did not mean that they had clinical PS, since they were not showing signs of septicemia. These results means that the animals are actually carrier, and pose risks for human health. During slaughter, the carcass may be contaminated by animal's feces containing Salmonella (25).

The incidence of $B$. hyodysenteriae detected in the present study was lower that those described by Scarcelli et al. (21) and Barcellos et al. (2). In different regions in Brazil, these authors reported a incidence of $9.1 \%$ and $13.5 \%$, respectively. The incidence of $B$. pilosicoli was also lower than the prevalence of $7.2 \%$ (157206) reported by Barcellos et al. (2). The difference between our findings and those reported by Barcellos et al. (2) and Scarcelli et al. (21) can be explained by regional differences, as well as by the use of antimicrobials in the studied herds. It has been reported that the antibiotic use can reduce the isolation and detection rates of Brachyspira from swine feces (2). The isolation of $B$. hyodysenteriae from feces of pigs without clinical signs of diarrhea is infrequently, but $B$. pilosicoli can be present in these cases (11).

The detection and identification of porcine intestinal spiroquetes by PCR- restriction fragment length polymorpism analysis of ribosomal DNA encoding 23S rRNA was described by Barcellos et al. (3). This technique was shown to be useful for identification of pathogenic spiroquetes, as B. pilosicoli and $B$. hyodysenteriae, but was more time-consuming, laborintensive and expensive than M-PCR.

The studied combination of agents reinforces the importance of using the M-PCR assay for the diagnosis of enteric diseases in pigs. The use of M-PCR technique included in a diagnostic panel provides a practical and cost-effective method for rapid detection of pathogens associated with swine diseases.

\section{ACKNOWLEDGEMENTS}

This study was supported by FAPESP-Fundação de Amparo a Pesquisa do Estado de São Paulo- research project 1998/7665-6.

\section{RESUMO}

\section{Identificação de agentes bacterianos de doenças entéricas em suínos por PCR-multiplex}

A enterite proliferativa suína, a espiroquetose colônica, a disenteria suína e a salmonelose são as doenças entéricas mais freqüentes em suínos das fases de crescimento e terminação no Brasil. O diagnóstico destas doenças através de técnicas bacteriológicas tradicionais é difícil, lento e no caso da enterite proliferativa suína, impossível. A detecção destes agentes através da reação de polimerase em cadeia é altamente sensível e específica e está se tornando uma ferramenta muito útil no diagnóstico em Medicina Veterinária. No presente estudo foram testadas duas técnicas de PCR sob a forma de "multiplex" para detecção e identificação simultânea dos agentes bacterianos envolvidos na enterite proliferativa suína, na espiroquetose colônica, na disenteria suína e na salmonelose em amostras de fezes diarreicas. O DNA obtido de culturas puras de cada agente sozinho ou misturado em diferentes combinações e concentrações foram amplificados utilizando a Multiplex PCR específica para Lawsonia intracellularis e Salmonella, ou Brachispyra pilosicoli e Brachispyra hyodysenteriae. Após a padronização, a M-PCR foi aplicada na detecção dos quatro agentes em 541 amostras de fezes diarreicas de suínos provenientes de diferentes Estados do Brasil. O agente mais freqüente foi Lawsonia intracellularis (13\%), seguido pela Salmonella spp. $(4,8 \%)$, B. hyodysenteriae $(1,4 \%)$, B. pilosicoli $(1 \%)$ e suas diferentes associações. Os resultados obtidos indicam que as duas reações testadas permitem a detecção destes quatro importantes patógenos entéricos de maneira rápida e específica.

Palavras-chave: enterite, PCR, suíno, bactéria, diagnóstico.

\section{REFERENCES}

1. Atyeo, R.F.; Stanton, T.B.; Jensen, N.S.; Suriyaarachichi, D.S.; Hampson, D.J. Differentation of Serpulina species by NADH oxidase gene (nox) sequence comparisons and nox- based polymerase chain reaction tests. Vet. Med., 67:47-60, 1999.

2. Barcellos, D.E.S.N.; Uzeda, M.; Ikuta, N.; Lunge, V.R.; Fonseca, A.S.K.; Kader, I.T.A.; Duhamel, G.E.. Prevalence of Brachyspira species isolated from diarrhoeic pigs in Brazil. Vet. Rec., 146:398403, 2000.

3. Barcellos, D.E.S.N.; Mathesen, M.R.; Uzeda, M.; Kader, I.T.A.; Duhamel, G.E. The detection and identification of porcine intestinal spiroquetes by PCR- restriction fragment length polymorpism analysis of ribosomal DNA encoding 23S rRNA. Vet. Microbiol., 75:189-198, 2000.

4. Boom, R.; Sol, C.J.A.; Salimans, M.M.M.; Jansen, C.L.; Dillen, P.M.E.W.; Noordaa, J. van der. Rapid and simple method for purification of nucleic acids. J. Clin. Microbiol., 28:595-503, 1990.

5. Braun, L.J.; Chase, C.C.L. Diagnostic porcine polymerase chain reaction assay: The future is here. Swine Health Prod., 7:37-40, 1999. 
6. Chang, W.L.; Wu, C.F.; Wu, Y.; Kao, Y.M.; Pan. M.J. Prevalence of Lawsonia intracellularis in Swine Herds in Taiwan. Vet.Rec., 141:103104, 1997.

7. Elder, R.O.; Duhamel, G.E.; Schafer, R.W.; Mathiesen, M.R.; Ramanathan, M. Rapid detection of Serpulina hyodysenteriae in diagnostic specimens by PCR. J. Clin. Microbiol., 32:1497-1502, 1994.

8. Elder, R.O.; Duhamel, G.E.; Mathiensen, M.R.; Erickson, E.D.; Gebhart, C.J.; Oberst, R.D. Multiplex polimerase chain reaction for simultaneous detection of Lawsonia intracellularis, Serpulina hyodysenteriae and Salmonella in porcine intestinal specimens. $J$. Vet. Diagn. Invest., 9:281-286, 1997.

9. Duhamel, G.E. Differential diagnoses for reduced grow/finish performance associated with colonic spirochetosis and proliferative enteritis. In: The $37^{\text {th }}$ George A. Young Swine Conference \& Annual Nebraska SPF Swine Conference. Proceeding. Lincon., 146-152, 1995.

10. Harel, J.; Forget, C. DNA probe and polymerase chain reaction procedure for the specific detection of Serpulina hyodysenteriae. Mol. Cell. Probes, 9:111-119, 1995.

11. Hampson, D.J.; Trot, D.J. Swine Dysentery. In: Straw, B.; D’Allaire, S.; Mengeling, W.L.; Taylor, D.J. (eds) Diseases of Swine, $8^{\text {th }}$ ed. Iowa University Press, Ames, Iowa. 553-561, 1999.

12. Jones, G.F.; Davies, P.R.; Rose, R.; Ward, G.E.; Murtaugh, M.P. Comparison of Techniques for Diagnosis of Proliferative Enteritis of Swine. Am. J. Vet. Res., 54:1980-1985, 1993.

13. Jordan, D.M.; Hoffman, L.J.; Roof, M.B.; Larson, D.; Schwartz, K. Detection of Lawsonia (Ileal Symbiont) intracellularis in Iowa Swine Using polymerase Chain reaction Methodology. In: America Association Swine Practitioners Meeting, Nashville, Proceedings, 179-182, 1996.

14. Kim, O.; Kim, B.; Chae, C. Prevalence of Lawsonia intracellularis in selected pig herds in Korea as determined by PCR. Vet. Rec., 143:587-589, 1998.

15. Kunkle, R.A.; Harris, D.L.; Kinyon, J.M. Autoclaved liquid medium for propagation of Treponema hyodysentariae. J. Clin. Microbiol., 24:669-671, 1986.
16. McOrist, S.; Gebhart, C. J. Porcine proliferative enteropathies. In: Straw, B.; D’Allaire, S.; Mengeling, W.L.; Taylor, D.J. (eds) Diseases of Swine, $8^{\text {th }}$ ed. Iowa University Press, Ames, Iowa, 521-534, 1999.

17. Moreno, A.M.; Baccaro, M.R.; Coutinho, L.L. Lawsonia intracellularis detection in swine feces from important producing regions in Brazil. In Press, Arq. Inst. Biol., 69, 2002.

18. Muniappa, N.; Mathiesen, M.R.; Duhamel, G.E. Laboratory identification and enteropathogenicity testing of Serpulina pilosicoli associated with porcine colonic spirochetosis. J. Vet. Diagn. Invest., 9:165-171, 1997.

19. Ochiai, S.; Adachi, Y.; Katsumi, M. Unification of the genera Serpulina and Brachyspira, and proposal of Brachyspira hyodysenteriae comb. nov., Brachyspira innocens comb. nov. and Brachyspira pilosicoli comb. nov. Microbiol. Imunnol., 41:445-452, 1997.

20. Park, N.Y.; Chung, C.Y.; McLaren, A.J.; Atyeo, R.F.; Hampson, D.J. Polymerase chain reaction for identification of human and porcine spirocaetes recovered from cases of intestinal spirachetosis. FEMS Microbiol. Lett., 125:225-230, 1995.

21. Scarcelli, E.; Genovez, M.E.; Rojas, S.; Bersano, J.G.; Shotten, M.H. Avaliação da presença de Campylobacter spp em suínos: sua relação com a ocorrência de disturbios entéricos. Rev. Microbiol., 22:112115,1991

22. Stone, G.G.; Oberst, R.D.; Hays, M.P.; McVey, S.; Chengappa, M.M. Detection of Salmonella serovars from clinical samples by enrichment broth cultivation-PCR procedure. J. Clin. Microbiol, 33:1742-1749, 1994.

23. Takahashi, K.; Kishimoto, Y.; Yamamoto, A.; Nose, Y.; Odagiri, Y. Porcine Proliferative Enteropathy Caused by Lawsonia intracellularis in Japan. In: 15 International Pig Veterinary Society Congress, Birmingham, Proceedings. Birmingham. 3:109, 1998.

24. Thomson, J.R.; Smith, W.J.; Murray, B.P. Investigations into field cases of porcine colitis with particular reference to infection with Serpulina pilosicoli. Vet. Rec., 142:235-239, 1998.

25. Schwartz, K.J. Salmonellosis. In: Straw, B.; D' Allaire, S.; Mengeling, W.L.; Taylor, D.J. (eds) Diseases of Swine, $8^{\text {th }}$ ed. Iowa University Press, Ames, Iowa. 535-551, 1999. 